Rassim Younes $^{1 *}$, Abelhamid Sadeddine', Mohand Amokrane Bradai ${ }^{1}$, Sahraoui Aissat ${ }^{2}$, Abderrahim Benabbas ${ }^{3}$

1 Laboratory of Mechanics, Materials and Energetic (L2ME). Faculty of Technology, University of Bejaia, Algeria

${ }^{2}$ Research Laboratory of Industrial Technologies. Department of Mechanical Engineering. Faculty of Applied Sciences, Ibn Khaldoun University, Algeria

${ }^{3}$ Laboratory of Processes for Materials, Energy, Water and Environment. Faculty of Science and Technology, University of Bouira, Algeria

*younesrassim@gmail.com

\title{
INVESTIGATION ON THE INFLUENCE OF TEMPERING ON MICROSTRUCTURE AND WEAR PROPERTIES OF HIGH ALLOY CHROMIUM CAST IRON
}

\begin{abstract}
Mechanical properties, wear resistance and impact resistance of a high-alloy chromium cast iron used in the fabrication of grinding balls have been studied. A rank of tempering heat treatments under several temperatures $500^{\circ} \mathrm{C}, 525^{\circ} \mathrm{C}, 550^{\circ} \mathrm{C}$ and $575^{\circ} \mathrm{C}$ was performed after austenitized at $1050^{\circ} \mathrm{C}$. The Scanning Electron Microscope (SEM) and X-ray Diffraction (XRD) techniques have been used to characterize the microstructures and identify the phases. The wear balls tests were conducted in a rotating drum with a velocity $0.5 \mathrm{r} / \mathrm{s}$. The tribological tests were carried out by evaluated a weight loss as function time. The measurement of the rebound resilience was determined by Charpy impact tests. The results of XRD showed the presence of the martensite, carbides type $\mathrm{M}_{7} \mathrm{C}_{3}$ and $\mathrm{M}_{2} \mathrm{C}$ for all tempering heat treated. The hardness of the sample increased after the tempering and reach nearly $65 \mathrm{HRC}$ at $1050^{\circ} \mathrm{C}$. In another hand, it decreased after the tempering treatment it could be explained by precipitation of the carbides type $\mathrm{M}_{2} \mathrm{C}$.
\end{abstract}

Keywords: High-alloy chromium cast iron; microstructure; wear, resilience

\section{INTRODUCTION}

The laboratories has been involved in the production and characterization of metastable and innovative materials. Researcher reach to use efficient of properties of materials alloying in order to increase the best way to refine-grained. The aim of project concerns ball milling which is mainly used in different hard manufactories. The most important field of research, it hope to reach mechanical properties of ball mill. In ball mills, the energy input to the powder charge is came from movement of the cylinder room, In the rotating mills, the steel balls roll along a circular arc on the wall of chamber, and the powder charge is spread on the inner surface of the chamber. Ball mills used in the cement industry used to fragment suspended 
particles by stirring a grinding area. They are used to transform the fine rock whose gauge is less than one millimeter (average dimensions are 15 microns) [1-4]. The multiple impacts may damage the ball and reduce the efficiency of the grinding. The mechanical stresses are incurred of diverse origins: shearing due to contact with the wall of the mill, contact between the balls, peeling caused by wear and shock [5-10].

The during life of these materials can be limited by the ability of the grinding ball to resist of periodical mechanical shocks and also depends on its ability to withstand the action of abrasive products with a less mass losses. To link between mechanical and technological requirements, these balls are made of cast high-alloy chromium (10 to 13\% chromium) [1112]. These casts irons are listed in ISO 21988 [13-17]. However, the balls shall be subjected to appropriate heat treatments for improving their mechanical properties. Under these conditions, among the many parameters and criteria to be retained during these heat treatments are the austenitization temperature, the time and tempering [18-22].

For high chromium cast iron with a $\mathrm{Cr}$ rate between 11-18 percent (hypo-eutectic composition), the behaviour of solidification begin with the nucleation of dendritic austenite primary $(\mathrm{Y})$, followed by the formation carbides of $\mathrm{Y}+\mathrm{M} 7 \mathrm{C}_{3}$ eutectic. The growth mechanism of $\mathrm{M}_{7} \mathrm{C}_{3}$ carbides and the microstructure formation have been well detail by several researchers $[23,26]$.

In the previous study of the effect of various kinds of recovering on microstructure and mechanical properties of the high chromium cast iron was studied between 200, 400 and 600 ${ }^{\circ} \mathrm{C}$. The results showed that, modification of the carbide morphology in cast iron has been greatly improved especially between 450 and $600^{\circ} \mathrm{C}$ [22]; for this reason we would to investigate on efficient temperature to describe the phenomena of carbide precipitation

The aim of this work is to study the effect of tempering on the microstructure and mechanical behavior of the of high alloy Chromium Cast Iron, we will present the microstructural and structural characterization of the samples at various temperatures by using the scanning electron microscope (SEM), and XRD diffraction. Then the Hardness, wear and resilience had been investigated according to various applied parameter.

\section{EXPERIMENTAL}

\section{Materials}

The materials used in the present investigation was an high alloy chromium cast iron steel with the following nominal chemical composition (wt \%) obtained by using analysis X-rays fluorescence which's represented in table 1 .

Table 1. Chemical composition of the high chromium cast iron, wt.\%

\begin{tabular}{cccccccccc}
\hline $\mathrm{C}$ & $\mathrm{Cr}$ & $\mathrm{Cu}$ & $\mathrm{Ni}$ & $\mathrm{Mn}$ & $\mathrm{Fe}$ & $\mathrm{Mo}$ & $\mathrm{Si}$ & $\mathrm{V}$ & $\mathrm{Mn}$ \\
\hline 3.0 & $9-10$ & 0.119 & 3.0 & 0.231 & $\mathrm{Bal}$ & 0.2 & 0.7 & $<0.01$ & 0.3 \\
\hline
\end{tabular}

It was machined to the cylindrical geometry with $8 \mathrm{~mm}$ in diameter. These samples were carried out to hardening heat treatment by an austenitization temperature at $1050^{\circ} \mathrm{C}$ and tempering at different temperatures from $500^{\circ} \mathrm{C}$ to $575^{\circ} \mathrm{C}$ with a step of $25^{\circ} \mathrm{C}$ for 5 hours. 


\section{Microstructure Investigations}

The surface of samples was ground using SiC paper with grit sizes and finally polished with alumina. Microstructures firstly were observed on its surfaces using scanning electron microscope (SEM) in high vacuum, whereas the different phases which is present on samples at different process of heat treatment was investigated using X-ray diffraction, these X-rays diffraction patterns were recorded with a $\mathrm{Cu}$-anode $\mathrm{X}$-ray tube and a curved graphite monochromatic in the diffracted beam.

The presence of blemish in these materials creates a significant background; to improve the ratio of peak/background ratio, an acquisition time of $40 \mathrm{~s}$ was used step of $0.04^{\circ}$ over the $30^{\circ}-100^{\circ}$. The identification of the crystal phases present in the coatings was performed using X'Pert HighScore software supported with the ICDD-PDF2 database.

\section{Mechanical pProperties}

Rockwell hardness indentation was carried out on the top of samples with a indenter applying a load of 30N. The equipment used is a Wolper kind DIA-TESTOR 2RC hardness meter, the hardness value was took as the mean of 10 measurements.

The wear rate was estimated by the mass losses of thermally treated ball after spending a specified time inside a drum of $98 \mathrm{~cm}$ in diameter and $148 \mathrm{~cm}$ high. The drum is filled with balls up to $30 \%$ of its capacity and driven at 28 cycle/min. The mass was mesured after 15 minutes by weighing using an electronic scale with a $0.1 \mathrm{~g}$ precision.

The measurement of the rebound energy (resilience test) were performed according to EN 10045 at impact velocity $5.52 \mathrm{~m} / \mathrm{s}$. The test method get to the impacting a test pieces with a falling mass, these ball is free to rebound and re-contact after impact druming. There are two methods specified for determining the rebound resilience: the pendulum method as used to measure the energy required breaking once a pre-notched. The equipment used in a pendulum machine is equipped with a clamping device, a centring reference of test specimens and a meter on which you can read the energy after broke. The samples of high alloy chromium cast iron balls have a normalized dimension, the angle through which the samples moves before impact is set to $\mathrm{V}$-notch $45^{\circ}$. The impact resistance $\mathrm{KCV}$ is equal to $\mathrm{W} / \mathrm{S}\left[\mathrm{J} / \mathrm{cm}^{2}\right]$.

P: Load (N)

h: height (m)

$\mathrm{KCV}$ : impact resistance $\left(\mathrm{J} / \mathrm{cm}^{2}\right)$.

\section{RESULTS AND DISCUSSION}

\section{Microstructure analysis of treated ball}

The SEM micrograph of the treated ball at $1050^{\circ} \mathrm{C}$ and maintained for 5 hours is shown in Figure 1.

The SEM micrograph showed that the microstructure of almost all treated samples present a significative differences between the intercellular regions and the areas around graphite nodules, as can be seen in Figure 1. Around the nodules, it was observed the presence of bainitic ferrite + retained austenite. Secondly, the intergranular surfaces was composed predominantly of high carbon martensite, probably formed by the transformation of unstable austenite during final cooling. These heterogeneities points out a pronounced segregation of elements during solidification. 


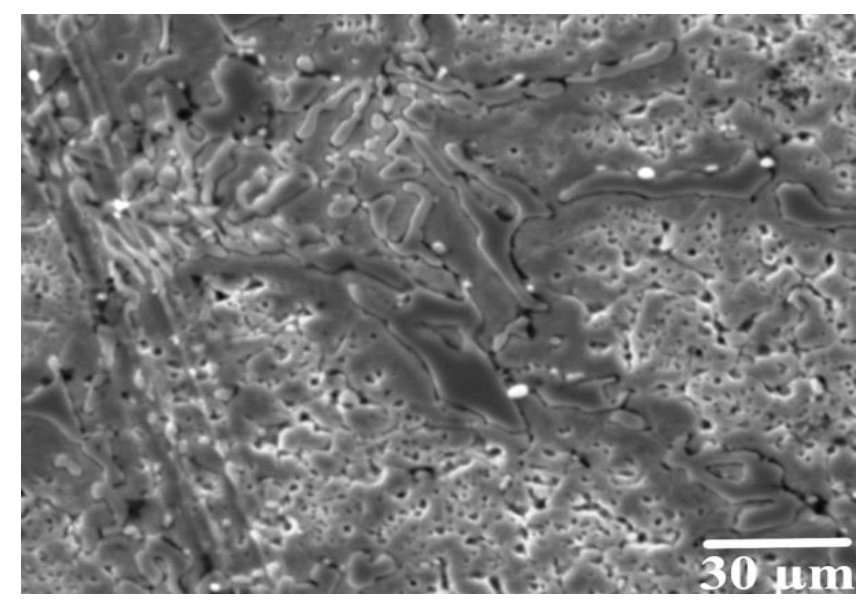

Fig. 1. SEM (Backscattered Electron) image of the treated ball held at $1050^{\circ} \mathrm{C}$ for 5 hours

Chemical elements such as chromium commonly segregate towards eutectic cells boundaries. When we comparing areas around the nodules and intercellular areas, it is like two different alloys with different compositions coexist. This phenomenon allowed to find precipitation of carbides especially area which had high ratio carbon like austenite, whereas in the intercellular areas, it will be transformed to martensite during final cooling. The XRD pattern of the sample treated at $1050^{\circ} \mathrm{C}$ held for 5 hours is represented by Figure 2 .

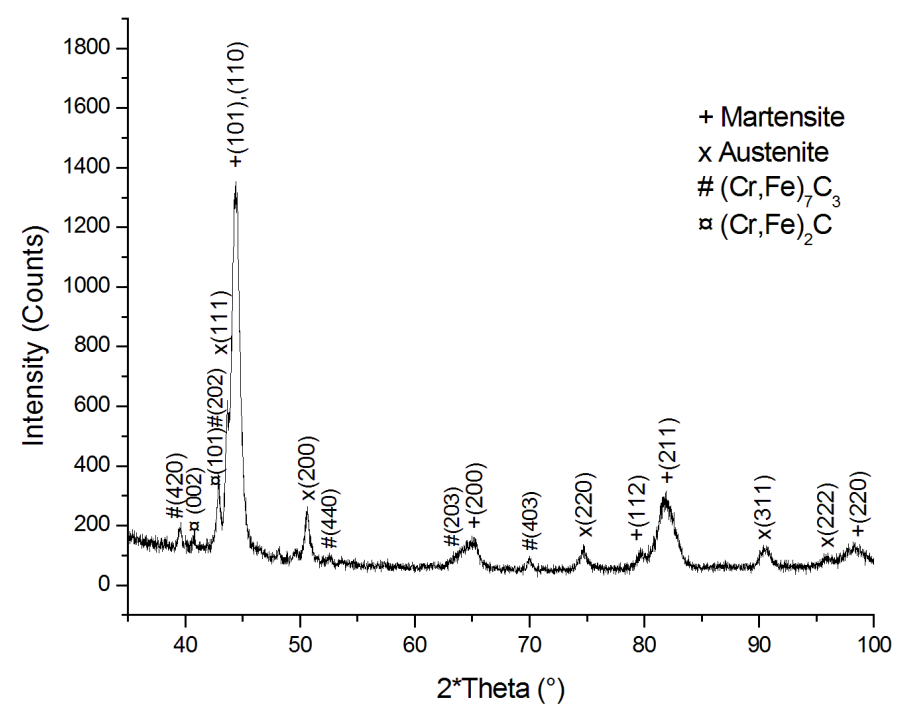

Fig. 2. X-ray diffraction spectrum of the sample treated at $1050^{\circ} \mathrm{C}$ held for 5 hours

The X-ray diffraction of our materials show peak of $\mathrm{M}_{2} \mathrm{C}$ (ICDD 00-36-1482) carbides which is formed from the precipitation of $\mathrm{M}_{7} \mathrm{C}_{3}$ (ICDD 00-35-0783) ones, we note also the presence of matrix which is mainly constituted by martensite and austenite phases. Furthermore, a deeply exploration of the Xray diffraction will be investigate by SEM on the same microstructure obtained of the sample treated at $1050^{\circ} \mathrm{C}$ and hold for 5 hours after that we find a better image showed the presence of carbides type $\mathrm{M}_{2} \mathrm{C}$ in the form of small grains type $(\mathrm{Cr}, \mathrm{Fe})_{2} \mathrm{C}$ (ICDD n ${ }^{\circ}$ 017-0333, 031-0619) (Figure 3). The presence of these carbides with differents form and different size is probably due to the holding time which impact on the morphology and the size of the secondary carbides, this form is very beneficial with regard to properties of the matrix [27-28]. 


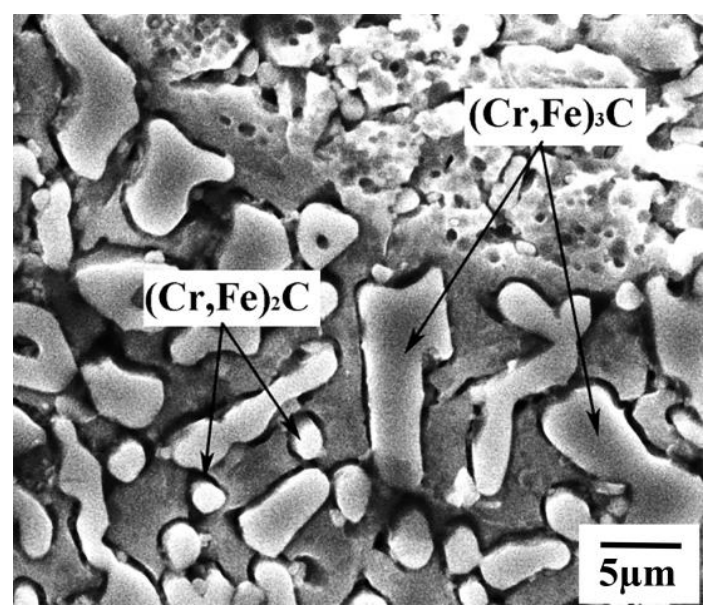

Fig. 3. SEM (Backscattered Electron) micrograph of the sample treated at $1050^{\circ} \mathrm{C}$ held for 5 hours

In order to obtain the efficient mechanical properties and reduce the residual stresses occurred during quenching, the treatment of tempering has been carried out at temperatures between $500^{\circ} \mathrm{C}$ and $575^{\circ} \mathrm{C}$ with steps of $25^{\circ} \mathrm{C}$ and a 5 hours hold each time for all samples.

\section{SEM Image of treated and tempered samples}

Microstructures of the treated samples were obtained after four recovery treatments and are shown in Figure 4.
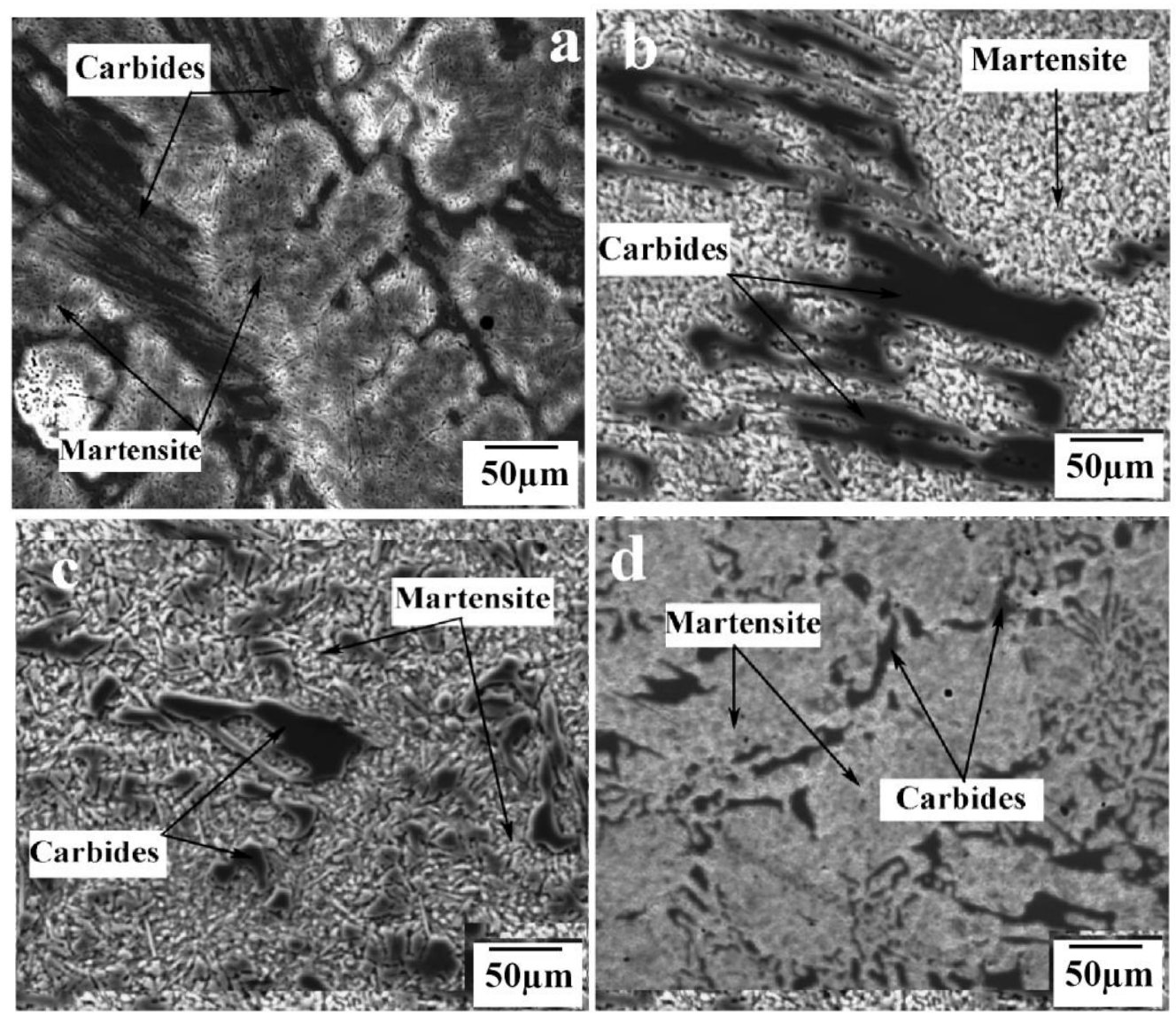

Fig. 4. SEM (Backscattered Electron) image of samples quenched at $1050^{\circ} \mathrm{C}$ held for $5 \mathrm{~h}$, a) tempering at $500^{\circ} \mathrm{C}$, b) tempering at $525^{\circ} \mathrm{C}, \mathrm{c}$ ) tempering at $550^{\circ} \mathrm{C}$, d) tempering at $575^{\circ} \mathrm{C}$ 
From the Figure 4 we could note two distinct phases a dark gray phase and another light gray. The microstructure of samples showed a combination of martensite and austenit. The grains had undergone fine recrystallization and these constituted the large part of the microstructure.

At $550^{\circ} \mathrm{C}$ and $575^{\circ} \mathrm{C}$ the structure was fully homogenized, during the cooling the microstructure are consisted of fine ferrite grains in which the martensitic (ICDD $\mathrm{n}^{\circ}$ 00-044-1290) was more uniformly distributed. The sample revealed a matrix in which shorter carbides flakes than in annealed sample existed. It was observed that there was many short $\mathrm{M}_{2} \mathrm{C}$ flakes surrounded with patches of uniformly distributed matrix grains as seen in Figure 3.

A highly recrystallized matrix grains with some secondary site was observed. This micrograph revealed that the microstructure of tempered samples is presented a number of carbides particles precipitated from the matrix, which indicated that the precipitate carbide particles decomposed by a process of solution in martensitic matrix (JCPDS n 00-044-1290) $[29,30]$.

\section{XRD of different samples}

Figure 5 showed X-Ray diffraction spectrum of sample had quenching and tempering treatments at $500^{\circ} \mathrm{C}, 525^{\circ} \mathrm{C}, 550^{\circ} \mathrm{C}$ and $575^{\circ} \mathrm{C}$ respectively, and they are maintained for 5 hours.
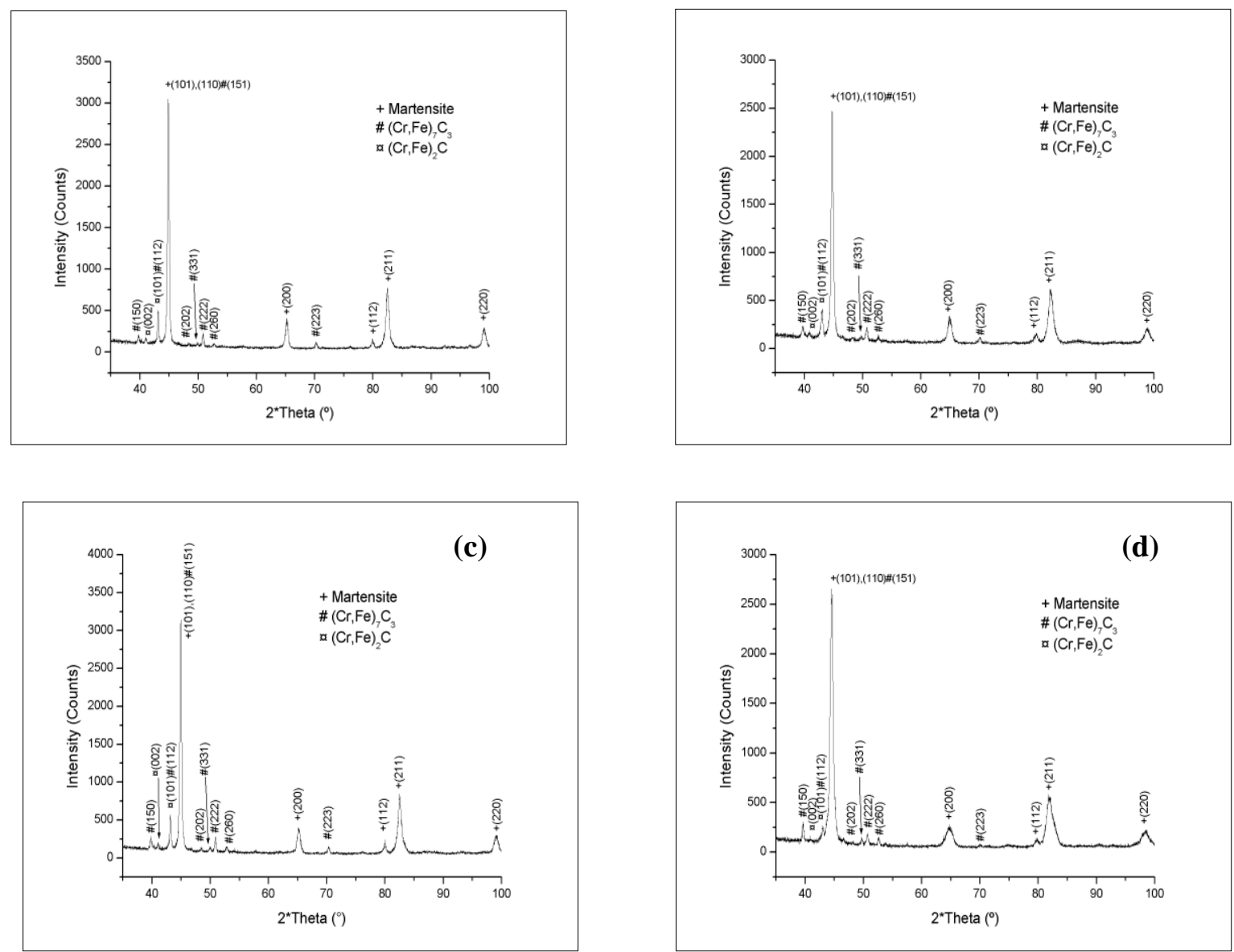

Fig. 5. X-ray diffraction spectrum of the samples treated at $1050^{\circ} \mathrm{C}$ held for $5 \mathrm{~h}$, a) tempering at $500^{\circ} \mathrm{C}$, b) tempering at $525^{\circ} \mathrm{C}, \mathrm{c}$ ) tempering at $550^{\circ} \mathrm{C}$, d) tempering at $575^{\circ} \mathrm{C}$ 
Figure 5 shows the diffractogram obtained from the samples treated at $1050^{\circ} \mathrm{C}$ held for $5 \mathrm{~h}$, and tempering at different temperature, comparison with the ICDD-PDF2 database has allowed the identification of different phases: it's clearly show presence a matrix which is formed mainly by martensite, we note also the formation of residual austenite (ICDD $n^{\circ}$ 031-0619) which is formed from the treated at $1050{ }^{\circ} \mathrm{C}$. Furthermore, the microstructures did precipitation further growth of chromium carbides within the annealed structure, this carbides consist of $\mathrm{Cr}_{7} \mathrm{C}_{3}$ (ICDD 00-35-0783) and martensite, $\mathrm{M}_{2} \mathrm{C}$ (ICDD 00-36-1482) carbides which form another phase enable this material to improve high surface hardness which promotes resistance to abrasive wear [31]. They are probably due to of decreasing local area of molybdenum, and carbon, in these regions

\section{Mechanical properties}

\section{Hardness test}

The hardness tests were performed to provide an estimate of the hardness of this new class of material.

Table 2. Hardness of the samples treated at $1050^{\circ} \mathrm{C}$ and maintained for 5 hours with tempering at $500^{\circ} \mathrm{C}, 525^{\circ} \mathrm{C}$, $550^{\circ} \mathrm{C}$ and $575^{\circ} \mathrm{C}$ for 5 hours

\begin{tabular}{ccc}
\hline Heat treatment tempering & Hardness HV & Hardness HRC \\
Austenitisation at $1050^{\circ} \mathrm{C} / 5 \mathrm{~h}$ & 998 & 64 \\
Tempering at $500^{\circ} \mathrm{C} / 5 \mathrm{~h}$ & 618 & 58 \\
Tempering at $525^{\circ} \mathrm{C} / 5 \mathrm{~h}$ & 695 & 60 \\
Tempering at $550^{\circ} \mathrm{C} / 5 \mathrm{~h}$ & 501 & 45 \\
Tempering at $575^{\circ} \mathrm{C} / 5 \mathrm{~h}$ & 473 & 42 \\
\hline
\end{tabular}

The data presented in table 2 show that the hardness measurements were recorded on these same samples. A significant drop in hardness can be noticed as shown in Table 2. The decrease in hardness after the tempering treatment for all treated samples could be explained by the precipitation of $\mathrm{M}_{2} \mathrm{C}$ type carbides which results in depletion of the carbon in the solid solution while relaxing residual stresses. Moreover, these $\mathrm{M}_{2} \mathrm{C}$ carbides strengthen the surface hardness while maintaining the core of the material malleable thereby promotes resistance to impact. Tempering treatment at $550^{\circ} \mathrm{C}$ and $575^{\circ} \mathrm{C}$, decomposed and broke martensite for produce the ferrite and carbides which decrease hardness of the matrix [32].

\section{Wear resistance}

Figure 6 sum up the results of the wear resistance expressed as a relative weight losses in function time of samples treated at $1050^{\circ} \mathrm{C}$ held for 5 hours and tempering at $500^{\circ} \mathrm{C}, 525^{\circ} \mathrm{C}$, $550^{\circ} \mathrm{C}$ and $575^{\circ} \mathrm{C}$ for 5 hours. 


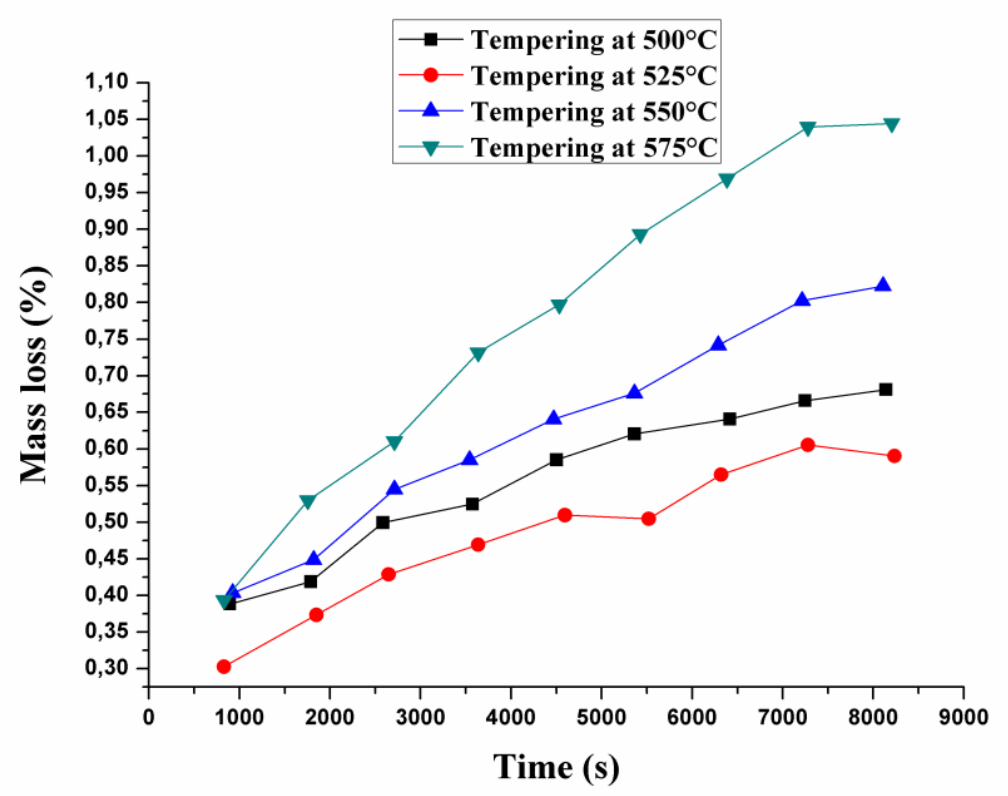

Fig. 6. Wear resistance as function time

Cast iron as raw state had a ferrite matrix, using in this state reduced their life time. Their microstructure and mechanical properties can be improved by performing through heat treatments of quenching and tempering.

The important results from this curve are:

- The evolution of this mass losses over time is stayed linear for all $50 \mathrm{~mm}$ diameter balls treated at $1050{ }^{\circ} \mathrm{C}$ held for 5 hours and tempering at $500^{\circ} \mathrm{C}, 525^{\circ} \mathrm{C}, 550^{\circ} \mathrm{C}$ and $575^{\circ} \mathrm{C}$ held for 5 hours.

- The balls tempering at $525{ }^{\circ} \mathrm{C}$, offer the best wear resistance in fact that mass losses noticed are less important. This is explained by the value of the high hardness of the balls

- The grinding balls which have tempering at $500^{\circ} \mathrm{C}, 525{ }^{\circ} \mathrm{C}, 550^{\circ} \mathrm{C}$ showed a clear slightly decreasing of mass losses for 30 minutes working and there was a stabilization after this period.

- For the ball tempering at $575^{\circ} \mathrm{C}$ held for 5 hours, it revealed that the mass loss is increasing regardless in function time but after 60 minutes the mass loss have a significant increase and the acceleration of these mass loses is the highest after 120 minutes. It can be explain by the lower hardness of balls which had an average 42 HRC.

\section{Fracture toughness test}

Resilience tests was carried out on different samples treated at $1050^{\circ} \mathrm{C}$ held after which they have undergone recovery treatments at $500^{\circ} \mathrm{C}, 525^{\circ} \mathrm{C}, 550^{\circ} \mathrm{C}$ and $575^{\circ} \mathrm{C}$. The obtained values of toughness are shown in Table 3: 
Table 3. Average values of the resilience of the samples treated at $1050^{\circ} \mathrm{C}$ held for 5 hours and tempering at $500^{\circ} \mathrm{C}, 525^{\circ} \mathrm{C}, 550^{\circ} \mathrm{C}$ and $575^{\circ} \mathrm{C}$

\begin{tabular}{ccc}
\hline $\begin{array}{c}\text { Austenisation at } 1050^{\circ} \mathrm{C} / 5 \mathrm{~h} \\
\text { and tempering }\end{array}$ & $\begin{array}{c}\text { Resilience } \mathrm{K}_{\mathrm{CV}} \\
(\mathrm{J} / \mathrm{cm} 2)\end{array}$ & $\begin{array}{c}\text { Hardness } \\
\text { HRC }\end{array}$ \\
\hline Tempering at $500^{\circ} \mathrm{C} / 5 \mathrm{~h}$ & 3.75 & 58 \\
\hline Tempering at $525^{\circ} \mathrm{C} / 5 \mathrm{~h}$ & 8.75 & 60 \\
\hline Tempering at $550^{\circ} \mathrm{C} / 5 \mathrm{~h}$ & 5.00 & 45 \\
\hline Tempering at $575^{\circ} \mathrm{C} / 5 \mathrm{~h}$ & 8.75 & 42 \\
\hline
\end{tabular}

Through the results obtained from Figure 7 , it was found that the samples treated at $1050^{\circ} \mathrm{C}$ and having undergone recovery treatments at $525^{\circ} \mathrm{C}$ and $575^{\circ} \mathrm{C}$ have higher toughness values than those treated and tempering at $500^{\circ} \mathrm{C}$ and $550^{\circ} \mathrm{C}$. This is due to the formation of fine carbides $\mathrm{M}_{2} \mathrm{C}$ type in the treated samples at $1050^{\circ} \mathrm{C}$; which therefore promotes the impact resistance [33].

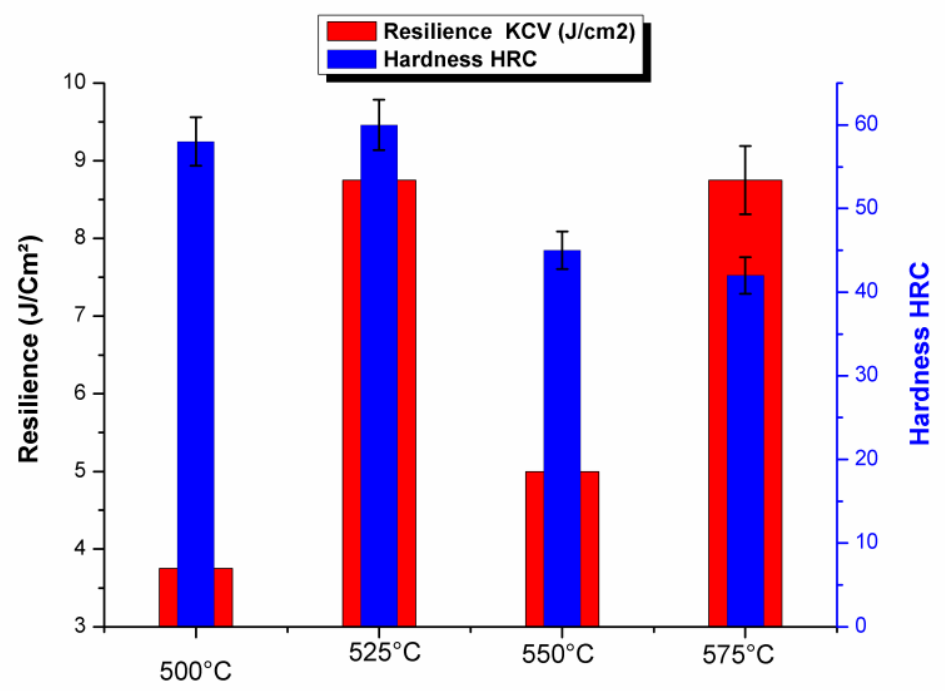

Fig. 7. Tempering effect on the impact resistance and hardness

The data depicted in Figure 7 show clearly that the tempering is needed to obtain kind of cast irons with better resilience energy. This behaviour could be explained by the retained austenite which increase the fracture toughness of samples. The higher results of impact energy were $8.75 \mathrm{~J} / \mathrm{cm}^{2}$ on samples tempering at $550^{\circ} \mathrm{C}$; the minus is lead to the samples which is temper at $500^{\circ} \mathrm{C}$. In all conditions, it was noted the presence of a process behaviour by the increasing values of impact energy after the increase, which decrease after certain time intervals. For each heat treatment temperature used in this study there is a time interval that produces optimized properties. If the heat treatment time is longer or shorter than the process the mechanical properties will increase.

From the Figure 7 we could say about fluctuation of these results, its nearly linked with microstructure especially the martensitic transformation is about uniform in all the mass. Generally, hardenings followed by a tempering at $525^{\circ} \mathrm{C}$ and $575^{\circ} \mathrm{C}$ give better hardness then 
that samples tempered at $500^{\circ} \mathrm{C}$ and $550^{\circ} \mathrm{C}$ ). The quench hardening realized on the grinding balls allows the formation of a hard and resistant martensite matrix (in black on the microstructure in Figure 4). This treatment helps the precipitation of carbides in white on the microstructure (Fig. 4) in the austenite, improves the hardness of austenite due to the reduction of the carbon content and increases the domain of the martensitic transformation. It is always associated with a certain quantity of residual austenite and it has hardness is great. The tempering allows softening the martensite, hence reducing the risks of cracking and reduce impact energy of resilience.

\section{CONCLUSIONS}

As result of this work, a choice of an appropriate austenisation temperature as well as an appropriate tempering heat treatment permits improvement of the impact resistance. Consequently, it is recommended: to improve the quality of the cast ion during its elaboration, to prevent infiltration of impurities during casting and to ensure proper distribution of alloying elements.

- There is the presence of $\mathrm{M}_{7} \mathrm{C}_{3}$ type carbides for all heat treatments carried out.

- Treatments of tempering at temperatures of $500^{\circ} \mathrm{C}$ and $525^{\circ} \mathrm{C}$ provide high hardness. These treatments increase the formation of another type of $\mathrm{M}_{2} \mathrm{C}$ carbides is due to the precipitation of $\mathrm{M}_{7} \mathrm{C}_{3}$ ones.

- The sample which has tempering at $525^{\circ} \mathrm{C}$ had been the best wear behaviour and impact tenses. Indeed, in the martensite coming from a recovery heat treatment, fine carbides which perform their function of reinforcing the matrix and the properties of this material are higher than those of the untreated cast-iron state.

\section{REFERENCES}

1. Shi F, Xie W, A specific energy-based size reduction model for batch grinding ball mill. Minerals Engineering, 70 (2015) 130-140.

2. Roop L, Singh R.C, Experimental comparative study of chrome steel pin with and without chrome plated cast iron disc in situ fully flooded interface lubrication, Surface Topography: Metrology and Properties, 3(6) (2018) 035001.

3. Lavakumar A, Physical metallurgy of ferrous alloys, book, Morgan \& Claypool Publishers pp. 8-1 to $8-45,2017$

4. Chen J.L, Ruan S.P, Wang L.J, Zhai J.P, Liu C, Effect of Austenite Grain Size on Hardenability and Impact Toughness of SCM435H, Materials Science Forum, 867 (2016) 5055 .

5. Li C, Guan Q, Cai J, Zhang C, Peng L, Jin Y, Surface alloying of gray cast iron with chromium by high current pulsed electron beam treatment, Materials Research Express, 5(6) (2017) 066518.

6. Florea C, Bejinariu C, Carcea I, Cimpoesu N, Chicet D.L, Savin C, Obtaining of High Cr Content Cast Iron Materials, IOP Conference Series: Materials Science and Engineering, 1(209) (2017) 012046. 
7. Scandian C, Boher C, De Melloc J.D.B, Rézaï-Aria F, Effect of molybdenum and chromium contents in sliding wear of high-chromium white cast iron: The relationship between microstructure and wear. Wear, 267 (2009) 401-408.

8. Fernández I, Belzunce F.J, Wear and oxidation behaviour of high-chromium white cast irons. Materials Characterization, 59 (2008) 669-674.

9. Kim C.K, Lee S, Jung J.Y, Effects of heat treatment on wear resistance and fracture toughness of duo-cast materials composed of high- chromium white cast iron and low-Chromium Steel. Metallurgical and Materials Transactions A, 3 (2006) 29-42.

10. Coronado J, Sinatora A, Abrasive wear study of white cast iron with different solidification rates. Wear, 267 (2009) 2116-2121.

11. Coronado J, Sinatora A, Load effect in abrasive wear mechanism of cast iron with graphite and cementite. Wear, 267 (2009) 6-11.

12. Fiset M, Huard G, Grenier M, Jacob C, Comeau G, Three-body impact-abrasion laboratory testing for grinding ball materials. Wear, 217 (1998) 271-275.

13. Idham M.F, Abdullah B., Syarif J, Jaffar A, Alias S.K., Saad N. H, Microstructure and XRD of ductile iron using annealing-tempering heat treatment process. Applied Mechanics and Materials, 393 (2013) 83-87.

14. Albertin E, Moraes S L, Maximizing wear resistance of balls for grinding of coal. Wear, 263 (2007) 43-47.

15. Ines F.P, Manuel A.J, Javier B.F, Rodriguez C, Influence of heat treatment on the microstructure of a high chromium steel used for the manufacture of rolling rolls. Materials Science Forum, 638-642 (2010) 3099-3104.

16. Carpenter S.D, Carpenter D, Pearce J.T.H, XRD and electron microscope study of a heat treated $26.6 \%$ chromium white iron microstructure. Materials Chemistry and Physics, 101 (2007) 49-55.

17. Carpenter S.D, Carpenter D, Pearce J.T.H, XRD and electron microscope study of an as-cast 26.6\% chromium white iron microstructure, Materials Chemistry and Physics, 85 (2004) 3240.

18. Aissat S, Sadeddine A, Bradai M.A., Younes R, Bilek A, Benabbas A. Effect of heat treatment on the hardness and wear of grinding balls. Metal Science and Heat Treatment, 59(5) (2017) 297-301.

19. Albertin E, Beneduce F, Matsumoto M, Teixeira I. Optimizing heat treatment and wear resistance of high chromium cast irons using computational thermodynamics. Wear, 271 (2011) 1813-1818.

20. Qin C, Hou Z.Z, Zhu H, Zhang Y, Zhao Q.H, Study on structure and properties of alloy nodular cast iron roller with laser heat treatment. Advanced Materials Research, 189-193 (2011) 790-794.

21. Weber K, Regener D, Mehner H, Menzel M, Characterization of the microstructure of highchromium cast irons using Mössbauer spectroscopy. Materials Characterization, 46 (2001) 399- 406.

22. Mouadji Y, Bradai M.A, Younes R., Sad-eddine A., Benabbas A, Influence of heat treatment on microstructure and tribological properties of flame spraying $\mathrm{Fe}-\mathrm{Ni}-\mathrm{Al}$ alloy coating. Journal of Central South University, 25(3) (2018) 473-481.

23. Szala M, Walczak M, Pasierbiewicz K, Kamiński M, Cavitation erosion and sliding wear mechanisms of AlTiN and TiAlN films deposited on stainless steel substrate. Coatings, (2019) 9(5) 340. 
24. Opapaiboon J, Sricharoenchai P, Inthidech S, Matsubara Y, Effect of carbon content on heat treatment behavior of multi-alloyed white cast iron for abrasive wear resistance. Materials Transactions, 56(5) (2015) 720-725.

25. Laird G.I.I. Microstructures of nickel-hard I, nickel-hard IV and high-chromium white cast irons. Ninety-Fifth Annual Meeting American Foundrymen's Society, (1991) pp. 339-357.

26. Boroń $€$, Tchórz A, Application of EDS microanalysis in the identification of inhomogeneities in surface protective layers on ductile cast iron parts, IOP Conference Series: Materials Science and Engineering 7 (2010) 012005.

27. Fu B.G, Li Z.Q, Zhao X.B, Shen Z, Li G.L, Liu J.H, Formation mechanism of spheroidal carbide in ultra-low carbon ductile cast iron. China Foundry, 13(5) (2016) 346-351.

28. Chiniforush E.A, Iranipour N, Yazdani S, Effect of nodule count and austempering heat treatment on segregation behavior of alloying elements in ductile cast iron. China Foundry, 13(3) (2016) 217-222.

29. Chakrabarti A.K. Kinetics of second stage graphitization in quenched alloy spheroidal graphite iron. Journal of British Foundryman, (1974)

30. Charkrabarti A.K, Das P.P, Tempering characteristic of quenched alloy spheroid graphite cast iron. Journal of British Foundryman, 67 (1988) 330-334.

31. Tabrett C.P, Sare I.R, Effect of high temperature and sub-ambient treatments on the matrix structure and abrasion resistance of a high-chromium white iron. Scripta Materialia, 25 (1998) $1747-1753$.

32. Wang J, Zuo R.L, Sun Z.P, Li C, Liu H.H, Yang H.S, Shen B.L, Huang S.J, Influence of secondary carbides precipitation and transformation on hardening behavior of a $15 \mathrm{Cr}-1 \mathrm{Mo}-$ 1.5V white iron. Materials Characterization, 55 (2005) 234- 240.

33. Carpenter S.D, Carpenter D, X-ray diffraction study of $\mathrm{M}_{7} \mathrm{C}_{3}$ carbide within a high chromium white iron. Materials Letters, 57 (2003) 4456-4459. 